\title{
ULTRAHANGOS HEGESZTÉS ALKALMAZÁSTECHNIKAI JELLEMZŐI
}

\section{APPLICATION FEATURES OF ULTRASONIC WELDING}

\author{
Bagyinszki Gyula $^{1}$, Bitay Enikö ${ }^{2}$ \\ ${ }^{1}$ Óbudai Egyetem, Bánki Donát Gépész és Biztonságtechnikai Mérnöki Kar, \\ Magyarország, 1081 Budapest, Népszínház u. 8. bagyinszki.gyula@bgk.uni- \\ obuda.hu
${ }^{2}$ Sapientia - Erdélyi Magyar Tudományegyetem, Müszaki és Humántudományok Kar, Románia, 540485 Marosvásárhely (Koronka), Segesvári út 1.C., ebitay@ms.sapientia.ro

\begin{abstract}
The technological advantages of ultrasonic welding: no need for any filler metal; small electrical transient resistance contacts can be made; thin materials can also be welded to thick materials; results in a helium-solid weld seam; the computer configuration of the welding parameters can easily be solved; clean and safe workflow (no sparks, flame and smoke); can be integrated into the production line. This article deals with some of the additional application features of this welding process.
\end{abstract}

Keywords: pressure welding, ultrasound, sonotrode, parameters, process variants

\section{Összefoglalás}

Az ultrahangos fémhegesztés alkalmazástechnikai előnyei: nem kell semmilyen hozaganyag; csekély elektromos átmeneti ellenállású kontaktusok készíthetők; vékony anyagok hegeszthetők vastag anyagokhoz is; hélium-tömör hegesztési varratot eredményez; a hegesztési paraméterek számítógépes beállítása egyszerüen megoldható; tiszta és biztonságos a munkafolyamat (nincs szikra, láng és füst); gyártósorba integrálható. Jelen cikk ezen hegesztési eljárás néhány további alkalmazástechnikai jellemzőjével foglalkozik.

Kulcsszavak: sajtoló hegesztés, ultrahang, szonotróda, paraméterek, eljárásváltozatok

\section{Fizikai alapok és eszközök}

A mikrosúrlódási (nagyfrekvenciájú, mikrométeres nagyságrendbe eső amplitúdójú rezgésből származó) energiát - az érintkező munkadarabok közötti, a szonotróda (mint hegesztő-szerszám) alakjának ill. méretének megfelelő kiterjedésű felületen (,,interfészen”) - hasznosító ultrahangos hegesztést tulajdonképpen a dörzshegesztés rezgetéssel (nem forgatással) megvalósított speciális esetének is tekinthetjük (1. ábra).

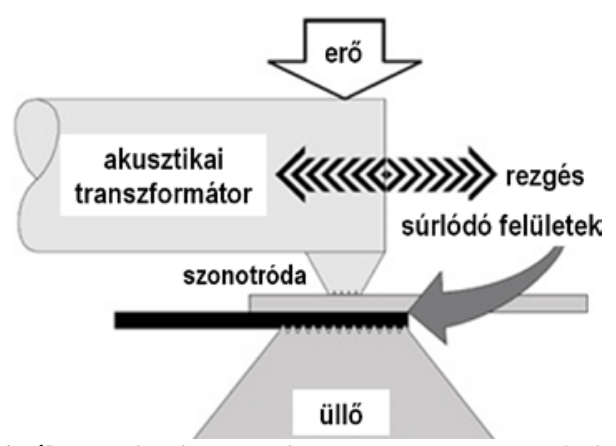

1. ábra. Ultrahangos hegesztés, mint nagyfrekvenciás rezgö dörzshegesztés 
Az 50 Hz-es hálózati elektromágneses rezgés (váltakozó feszültség ill. áram) által bevitt energia 20...40 kHz-es frekvenciájú mechanikai rezgéssé (ultrahanggá) ill. energiává alakul át. Ezt az energiaátalakítást egy rezonátor végzi, mely - a pozitív vagy negatív longitudinális magnetostrikció, mint a ferromágneses testek mágnesezettsége és mechanikai feszültségi állapota közti kapcsolat egyik megnyilvánulása

- vagy az elektrostrikció, mint reciprok piezoelektromos hatás jelenségén alapul.

A magnetostrikció alkalmazásakor az elektromos hálózati kis frekvencia nagy frekvenciássá alakításával és annak tekercsbe táplálásával létrehozott váltakozó axiális mágneses térerő mechanikai rezgésként (kis amplitúdójú hosszirányú rugalmas alakváltozásként) nyilvánul meg a mágneses mezőben célszerűen elhelyezett ferromágneses anyagban. A váltakozó árammal táplált tekercs ferromágneses anyagú (vas)magja erőteljes hosszrezgéseket végez, azaz ultrahang-hullámokat bocsájt ki, ha annak sajátfrekvenciája megegyezik a váltakozó áram frekvenciájával.

Az elektrostrikció az ún. aktív dielektrikumok sajátossága, ami váltakozó elektromos tér (feszültség) hatására jelentkező rugalmas deformáció, mechanikai rezgés, kellően nagy frekvencia esetében ultrahang. Ezen mechanikai rezgés amplitúdója rezonancia folytán akkor a legnagyobb, ha az elektromos tér rezgéseinek frekvenciája megegyezik a dielektrikum test valamelyik sajátfrekvenciájával.

Az ultrahangos hegesztésnél alkalmazott mechanikai rezgés egy szontródára kerül, hangolt akusztikus transzformátor(ok)on keresztül (2. ábra). A nyomóerő hatása alatt lévő alkatrészekre továbbított rezgés bontja a felületi szennyező- és oxidhártyákat, így tiszta, szabályozott diffúziós varratot hoz létre. Mivel az atomok a hegesztendő részek között kémiailag kapcso- lódnak, így valódi kohéziós kötés keletkezik.

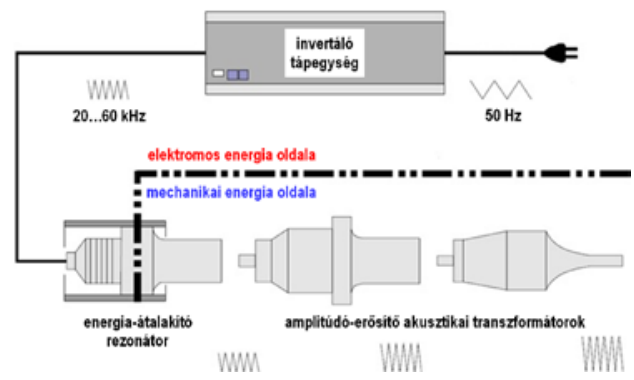

2. ábra. Ultrahangos hegesztő berendezés föbb részegységei

\section{Hegesztési paraméterek}

Az ultrahangos hegesztés kölcsönhatásban lévő fő technológiai paraméterei: a rezgés-időtartam, a rezgés-amplitúdó és a rezgés-irányra merőleges (normál) erő. A rezgéskeltés és -fenntartás teljesítmény-igénye:

$P=F \cdot A \cdot f=S_{m h} \cdot p_{\ell} \cdot \eta \cdot A \cdot f$

ahol $\mathrm{P}$ a teljesítmény [W], $\mathrm{F}$ az erő [N], A az amplitúdó $[\mu \mathrm{m}], \mathrm{f}$ a frekvencia $[\mathrm{Hz}], \mathrm{S}_{\mathrm{mh}}$ a pneumatikus munkahenger keresztmetszeti területe $\left[\mathrm{m}^{2}\right], \mathrm{p}_{\ell}$ a sürített levegő nyomása [Pa], $\eta$ a mechanikai hatásfok [-]. Ezzel az energiaigény egy hegesztési ciklusra:

$E=P \cdot \Delta t=F \cdot A \cdot f \cdot \Delta t=S_{m h} \cdot p_{\ell} \cdot \eta \cdot A \cdot f \cdot \Delta t$

ahol $\mathrm{E}$ az energia $[\mathrm{J}], \Delta \mathrm{t}$ a ciklus-idötartam vagy hegesztési idő [s]. Ez az időtartam a legtöbb kötéshez kevesebb, mint egy másodperc. Ha több energiára van szükség, és minden más technológiai paramétert változatlanul tartanak, a hegesztési időt kell növelni.

Jó minőségü hegesztett kötések létrehozásához szükséges, hogy az összekapcsolandó felületek tiszták legyenek. A nagyfrekvenciás súrlódás (összenyomás melletti rezgetés) jól tisztítja a kötendő felületeket a 
hegesztési folyamat elején. Ultrahangos fémhegesztéskor a felületállapotban (szervetlen nemfémes oxidréteg, szerves zsírvagy olajszennyezés) elforduló különbségeket az energiaérték módosításával - az időtartam állítása révén - lehet kompenzálni.

A rezonátor-akusztikai transzformátorszonotróda egység terheletlen állapotban minimális elektromos energiát igényel a rezgőmozgás megindításához és fenntartásához. A mechanikai terhelés növekedésével a mechanikai rezgés fenntartásához szükséges teljesítményigény növekszik. A nyomás hatására fellépő súrlódás eredményezi a hegedést az alapanyagok diffúziója ill. lokális „kavarása” által.

A nyomás növelésével - a többi paraméter állandó értéken tartása esetén - a hegesztési zóna mechanikai terhelése növekszik, így a vibráció fenntartásához szükséges erö- ill. teljesítményigény is nő. A megnövelt erö- ill. teljesítményszint miatt kevesebb időre van szükség a megfelelö energia beviteléhez, de figyelembe kell venni a tápegység terhelhetőségét is.

Az ultrahangos berendezés egy rezonáns akusztikai eszköz. Az amplitúdója a hosszirányú kiterjedés és összehúzódás különbsége $(5 \ldots 35 \mu \mathrm{m})$, amellyel a szerszám aktívan vibrál. Ez az amplitúdó megfelel a hegesztési felületen a súrlódási úthossznak. Ha az amplitúdó nő, a rezgés növekvő sebességének fenntartásához szükséges teljesítményigény is növekszik. Ezáltal kevesebb időre van szükség ugyanazon energia beviteléhez.

Az általános gyakorlatban a súrlódási amplitúdó egy hegesztési ciklus alatt állandó marad. Azonban a technikai fejlesztések lehetővé teszik a szonotróda felület amplitúdójának megváltoztatását a hegesztési ciklus folyamán. Ezt az amplitúdó profilozást vagy -léptetést (3. ábra) leginkább alumínium hegesztésénél használják a kötésszilárdság növelésére és a szerszámtapadás megakadályozására.

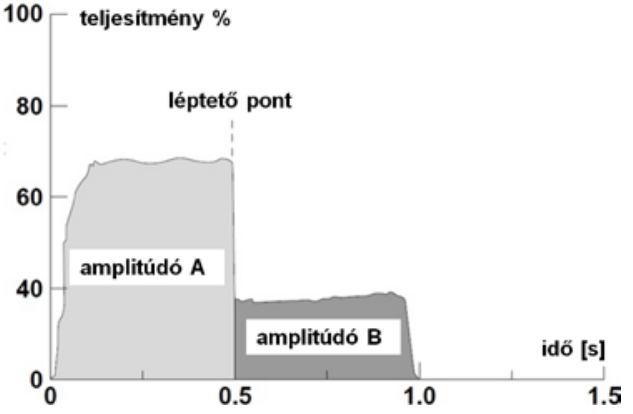

3. ábra. Amplitúdó-profilozás ultrahangos hegesztés során

Az ultrahangos eszközök használatakor a rezgések az akusztikus eszközön át terjednek, harmonikus rezonancia keletkezik, ami csomópontokból és „anticsomópontokból” áll. Ez eredményezi, hogy a rezonáns hullám átkerül a szerszámra (4. ábra).

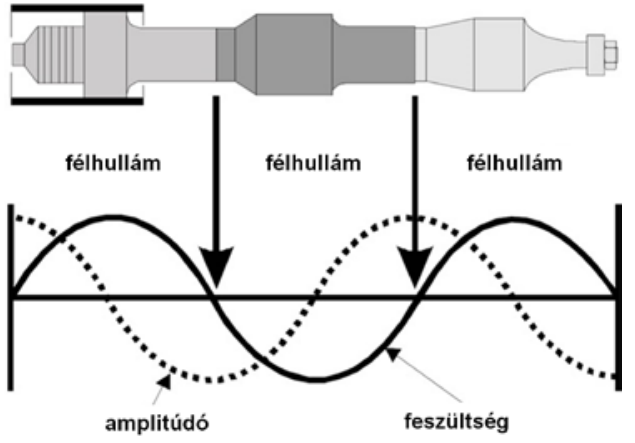

4. ábra. Harmonikus rezonancia ultrahangos eszközben

A rezonáns hullám-átvitel hatékonysága a rezonátor-akusztikai transzformátorszonotróda egység rezonancia frekvenciájától függ, és két fő tényező határozza meg: - a hang (rezgés) sebessége az anyagban, - az akusztikus egység geometriai alakja.

Lehetséges az amplitúdó és/vagy a nyomás növelésére olyan pontig, ahol a rendelkezésre álló teljesítmény már nem elegendő a rezgés keltéséhez vagy fenntartásához az adott mechanikai terhelés alatt. Ezen a ponton a tápegység megáll, ami túl- 
terheléses állapotot eredményezne. A rendszer elektronikus áramkörei megvédik a tápegységet, ha ilyen túlterhelési állapot bekövetkezik.

$\mathrm{Az}$ ultrahangos hegesztés a rugalmas hiszterézis, az illesztési súrlódás és a képlékeny deformáció kombinált hatásai folytán lokalizált hőmérséklet-emelkedést eredményez. A hegesztési felületek megközelítőleg a fémek olvadási hőmérsékletének 1/3-át érik el, így a hegesztett anyagok fizikai tulajdonságai gyakorlatilag nem változnak meg. Mivel az ultrahangos hegesztési folyamat exoterm (hőtermelö) reakció, a hegesztési idő növelése a hegesztési hömérsékletet is növeli.

\section{Eljárásváltozatok}

Az ultrahangos ponthegesztés során a rezgőmozgást az átlapoltan illesztett darabok közül a vékonyabbra $(0,005 \ldots 3 \mathrm{~mm})$ közvetítik. A darabok összenyomását biztosító erővel terhelt szonotróda ezzel a darabbal együtt rezegve hoz létre hegesztett kötést. Fontos, hogy a munkadarabok között jöjjön létre relatív elmozdulás, ne pedig a szonotróda és a felső munkadarab között. Lehetőség van azonos vagy eltérő anyagminőségü lemezek és huzalok összekötésére.

Az ultrahangos vonalhegesztés folyamatossá tett ponthegesztés, amelynél a tárcsakiképzésü, folyamatos forgómozgást végző szonotróda és üllő között áthaladó, átlapolt vékony lemezek között alakul ki a hegesztett kötés.
Ultrahangos kör(vonal)hegesztéskor a csőalakú szonotróda tengelye körüli alternáló mozgását pl. három rezgő egység biztosítja és így a hegesztés során a szonotróda csőszerü homlokfelületével közel megegyező méretü és alakú varrat jön létre.

\section{4. Összegzés}

Egy ultrahangos fémhegesztési feladat a hegesztendő anyagminőség és annak vastagsága által definiált. Ezekhez kell - a rendelkezésre álló berendezést alapul véve - a mechanikai (ill. az elektromos) teljesítményt, a frekvenciát, az amplitúdót, a nyomóerőt és a hegesztési időt meghatározni, tekintettel az anyag rezgéscsillapító képességére is.

\section{Szakirodalmi hivatkozások}

[1] Szunyogh László (föszerk.): Hegesztés és rokon technológiák Kézikönyv, Gépipari Tudományos Egyesület, Budapest, 2007, 3.6.2. Ultrahangos hegesztés, 299-303.

[2] Bitay Enikő - Bagyinszki Gyula: Robotok és a sajtoló hegesztések fejlesztései, XXI. Fiatal Müszakiak Tudományos Ülésszaka, Kolozsvár, 2016. március 17.; 5. Müszaki Tudományos Közlemények - Erdélyi Múzeum-Egyesület, 101-104.

[3] Szilágyi Mihály - Kovács Tünde: Ultrahang hegesztés alkalmazása alumínium lemeznél, Proceedings of 8th International Engineering Symposium at Bánki, Paper 55, 2016

[4] Welder Touchscreen Controller - Instrution Manual - 2.5 Ultrasonic Theory, Branson Ultrasonic Corporation, Danbury, 2017

[5] Budó Ágoston: Kísérleti fizika I-III., Tankönyvkiadó, Budapest, 1985 